\title{
Prognostic significance of regional edema and quantitative assessment of late gadolinium enhancement in patients with acute myocarditis
}

\author{
Emmanuelle Vermes, ${ }^{*}$ Helene Childs, Matthias G Friedrich \\ From 2011 SCMR/Euro CMR Joint Scientific Sessions \\ Nice, France. 3-6 February 2011
}

\section{Background}

Standard diagnostic CMR criteria for acute myocarditis have been proposed (ie Lake Louise criteria) based upon the any 2 of 3 approach which includes the presence of myocardial edema (T2), hyperemia/capillary leakage (early Gd enhancement: EGE) as well as fibrosis (late enhancement: LGE). However, there is a lack of prognostic data using these criteria. The aim of this study was to evaluate the diagnostic CMR criteria for the prediction of functional outcome in patients with myocarditis.

\section{Methods}

We studied 24 patients referred for acute myocarditis during the acute phase and 1 year thereafter. CMR studies included T2 weighted and contrast-enhanced T1 weighted (early and late enhancement) with a quantitative assessment of the regional and LGE.

\section{Results}

In the acute phase, edema (regional and /or global) was present in 67\%, EGE in $62.5 \%$ and LGE in 54\%. Edema \%LV (2SD) was: 27.3 \pm 7.8 ; LGE \%LV (2SD) was 20.5 \pm 14.2. At follow-up, EF significantly increased from $57 \pm$ $5.5 \%$ to $60 \pm 4.5 \%(\mathrm{p}<0.001)$. In a univariate analysis, LGE\% LV was correlated to the change in EF over 1 -year $(\mathrm{r}=0.704, \mathrm{p}=0.04)$, in a multivariate analysis (linear regression), the combination of LGE\%LV and regional edema serves as an independent predictor of an increase of $\mathrm{EF}(\mathrm{F}=5.13, \mathrm{p}=0.017)$

\section{Conclusion}

In our preliminary experience, the combination of LGE with regional edema was an independent predictor of functional recovery during a 1 year follow-up.

Published: 2 February 2011

doi:10.1186/1532-429X-13-S1-P179

Cite this article as: Vermes et al:: Prognostic significance of regional edema and quantitative assessment of late gadolinium enhancement in patients with acute myocarditis. Journal of Cardiovascular Magnetic Resonance 2011 13(Suppl 1):P179.
Submit your next manuscript to BioMed Central and take full advantage of:

- Convenient online submission

- Thorough peer review

- No space constraints or color figure charges

- Immediate publication on acceptance

- Inclusion in PubMed, CAS, Scopus and Google Scholar

- Research which is freely available for redistribution
C Biomed Central

\section{Biomed Central}

(c) 2011 Vermes et al; licensee BioMed Central Ltd. This is an open access article distributed under the terms of the Creative Commons Attribution License (http://creativecommons.org/licenses/by/2.0), which permits unrestricted use, distribution, and reproduction in any medium, provided the original work is properly cited. 